\title{
E-Communication Adoption in Benin Public Administration: Challenges and Strategies
}

\author{
Alexis Abodohoui ${ }^{1,2}$, Muhammad Mohiuddin ${ }^{1,2} \& \mathrm{Zhan} \mathrm{Su}^{1,2}$ \\ ${ }^{1}$ Faculty of Administrative Sciences, Laval University, and CIRRELT, Canada \\ ${ }^{2}$ Stephen A. Jarislowsky Chair on International Business, FSA ULAVAL, Canada \\ Correspondence: Alexis Abodohoui, PAP 2310, Faculty of Administrative Sciences, Laval University, \\ Canada. Tel: 1-581-990-8282. E-mail: alexis.abodohoui.1@ulaval.ca
}

\author{
Received: October 18, 2013 Accepted: December 2, $2013 \quad$ Online Published: December 18, 2013 \\ doi:10.5539/ijbm.v9n1p43 URL: http://dx.doi.org/10.5539/ijbm.v9n1p43
}

\begin{abstract}
Smooth Communication channel is important for better public service delivery.E-communication is a new communication channel in developing countries that allowed in real time communication with the stakeholders. The objective of this paper is to examine enablers and impediments in e-communication adoption process as a strategic communication mean in the Benin Public Administration. It draws from the literature and analyzes the impediments facing e-communication adoption in developing countries and especially in Benin.The authors investigate the issue using data obtained by semi-structured interviews from Benin's ministry of Information and Communication Technology (ICT), international organizations reports and academic websites.
\end{abstract}

Keywords: E-communication, public administration, Benin, impediments

\section{Introduction}

Towards the second half of the $20^{\text {th }}$ century, a new and now thoroughly pervasive form of human communication evolved from Digital Information and Communication Technologies (ICTs). The growth of e-communication has been phenomenal over the last few years. It offers us with ever soaring medium of communication, enabling public administrations to reach out beyond their social networks, make new connections and satisfy and form some communities. Many companies and administrations have recognized the power of e-communication for engaging with customers, developing trust around their product and services and improving media visibility.

Digital communication between individual and organization has increased in the second half of the 1980s with the invention of the internet as a public network. It gained new momentum in 1990s with the development of e-commerce and internet protocol licensed. Beginning in that period until now, numerous researches were done about ICT usage in the developed countries (Abodohoui, 2010; Argarwal \& Prashad, 1997, 1999; Cheng, 2013; Davis, 1993; Jabeur, Mohiuddin, \& Karuranga, 2013; Krishnaswamy, Bonell, Venkatesh, Purandara, Lele, Kiran \& Rakesh, 2012; Tan \& Teo, 2000; Valier, 2006). In recent years, a remarkable growth has been observed in the developing countries and generally in African countries (Venkatesh \& Sykes, 2013).

Highly varied ICT has been found across African countries. African countries according to Ernst \& Young (2009) can be categorized into three ICT markets saturation: developed, emerging, and virgin. The developed category refers to countries where ICT penetration is above 50\% (such as South Africa with 98\%). Most of the African countries are located in the emerging market between 20 and $49 \%$. Those countries in the virgin category have ICT penetration rate below $20 \%$ of the population. The typical features of these countries are political instability and have highly regulated and controlled telecommunication sectors (e.g., The RDC and Zimbabwe). The International Telecommunication Union (ITU) and the Information for the Development Program (InfoDev) created "The ICT regulation toolkit" (ICTR) to provide a web based tool intended for ICT policymakers and regulators around the world (Martin, 2012).

By the end of 2012, about half of the world had access to the internet. This represents an increase of 566.4 percent over 2000. African countries account for 7 percent of the internet users while the Asian countries account for 44.8 percent (Internet World Stats, 2013). The Republic of Benin is a small West African country located between Nigeria and Togo. Since December 1994, Benin started to modernize its public administration 
and the "Framework on Administrative Reform." was more prolific than the legal stage (Batoko, 2004). Ministry of ICTs of Government of Beninhandles the co-ordination, control, and management of the new e-communication projects in accordance with established goals for ICT sector. The country projects active and vibrant integration in an open and interdependent information society by 2025 . Like most other emerging countries, Benin is emphasizing more on the development of information and communication technology (ICT) sector to increase economic growth. The biggest communication company in the country is Benin Telecoms, which is owned by the government. The major ICT revolution came with the introduction of cell phones during 2000. Currently there are four companies providing mobile phone services with MTN, Moov Benin, Glo communication and BBcom. Currently, the companies are starting to offer to their subscribers the ability to surf the net and read emails via their mobile phones, tablets and other mobile devices. Thus, the country expects to use ICT to improve the service offerings in the areas of education, health, agriculture, commerce and culture. The internet users as of June 2012 constitute 3.5 percent of the approximately ten millions of Benin's population. The Facebook subscribers on December 31st have been estimated to be 171,780 and the rate of internet penetration is 1.8 percent. The use of information and communication technology (ICT) turned out to be a key factor in the process of the wider development of the countries. Some research about e-Government in Nigeria show that ICT infrastructure help to improve public services. It ensures higher productivity and economic growth, foster national competitiveness and lead to the attainment of the vision 2020 (Asogwa, 2013).

E-communication has become increasingly necessary for communicating and exchanging information as we are migrating towards geographically dispersed but digitally connected workplaces. The benefits of using emails in the organization and associated productivity gains are well documented in the literature. Most of the theoretical frameworks and conceptual models of the ICT studies focus on the developed countries perspective, particularly, an American perspective (Zhu \& Kraemer, 2005) while the developing countries perspective is seldom addressed. However, there is no specific research about email communication implementation in the developing countries since these countries have improved their ICT level. Advance uses of ICT, such as the internet, online communication, online transaction, e-commerce, e-tax, e-service, enterprise system to name a few, are an important avenue for socioeconomic advancement of the developing African countries (Gupta, Diallo \& Marot, 2010). E-communication is considered as an important means of communication. It helps to maintain a business relationship. E-communication allows a firm or an organisation to access information and record communication with its suppliers and buyers (Abarchi \& Yong, 2011)

Overall e-mail is viewed as a communications tool enhancing productivity and competitive intelligence. But in some developing countries, for instance in Benin, this technique of communication is not yet well known and there are factorsthat do not facilitate the implementation of e-mail in the public organization. The aim of this paper is to examine the benefits and status of emailcommunication in Benin, the barriers to the accomplishment of the goal and strategies needed to proceed forward in implementing the e-communication in the public organizations. This paper further exposes the challenges and strategies for e-communication initiatives in Benin and other developing countries in Sub Saharan region.

We have undertaken semi-structured interview of 15 senior managers and collected publicly and privately available documents on adoption of e-communication channels in public organizations in Benin. We then used content analysis approach to analyze the transcript and related documents collected from international institutions and from various departments of ministries in Benin. The following section provides a literature review. The third section describes the research methodology. The fourth provides solutions about how to increase the benefits of email communication for the public administration. Finally, the fifth section summarizes the discussion, limitation and future work.

\section{Literature Review}

Different theories and models have been used to inquire ICT adoption-diffusion behavior in various fields of study. Most of these theories root back to the Theory of Reasoned Action (Fishbein \& Ajzein, 1975), Diffusion Theory (Rogers, 1983), Theory of Planned Behavior (Ajzen, 2002) and Technology Acceptance Model (TAM) (Davis, 1989). Most of these four theories are widely applied to individual and organizational perspectives in order to address the ease of operation and usefulness of the technology adoption.

Rogers's innovation-diffusion model show that factors which influence the diffusion of an innovation are the characteristics of the innovation, communication channels, and social system, all interacting over time. The five characteristics of an innovation which affect the rate of diffusion of that innovation are: relevant advantage (the degree to which the potential adopter perceives the innovation to be better than its forerunner); compatibility (the degree to which the potential adopter perceives the innovation as being in line with his/her existing values, 
needs and pas experiences); complexity (the degree to which the potential adopter experiences the innovation's results are evident to others); and "trialability" (the degree to which the potential adopter will try-out the innovation before adoption. Moore and Benbasat (1991) two more characteristics to the model of Rogers namely: image (the degree to which a potential adopter's image or status is perceived to be enhanced in his/her social system because him/her using innovation) and voluntariness of use (the degree to which the potential adopter is perceived to willingly make use of the innovation). Taken together, these six characteristics are the very substance of information technology adoption and use (Weilback \& Byrne, 2010).

Fishbein and Ajzen (1975) devised a method to predict human behavior. To do this, they assumed that humans were usually rational, logical, and they used systematic information available. According to the reasoning of the two researchers, people consider the consequences of their actions before they decide whether or not to adopt a certain behavior (Ajzen \& Fishbein, 1980). They have come to develop a theory which they could predict and understand the behavior and attitudes. This theory, which they called the Theory of Reasoned Action (TRA), suggests that the intention to act is an indicator of the most important attitudes behavior. According to this theory, attitudes interact with subjective norms to influence the intention to act, and that determines the behavior. As has already been described in previous work, we analyze further the second theory that these same authors later developed. The theory of planned behavior (TPB) aims to complement and complete the first developed theory.

After discovering some imperfections in the structure of it, Ajzen and Fishbein have changed the theory of reasoned action (TRA) by adding a third element: the perceived behavioral control. This concept is defined by the individual's belief in the idea that it will be easy or not to adopt a certain behavior. This element is intended to compensate for situations in which people have little control (or believe they have little control) on their behaviors and attitudes. The main idea derives from the Theory of Planned Behavior (TPB) is as follows: individuals are not likely to develop a strong intention to act and behave in a certain way if they believe do not have the resources or opportunities to get there, even if they have favorable attitudes toward the behavior in question and if they feel that their family members would approve the behavior (subjective norms). The educational implications of this theory are important in the field of adoption of e-mails, because they can be used to guide the actions of citizens by providing them with opportunities to develop their intention to act.

The Technology Acceptance Model (TAM) was developed byDavis on the work of Fishbein and Ajzen (1975) and has been specifically developed, first, to identify the determinants that play a role in the acceptance of the general purpose computer. Second, to consider a variety of behaviors to use computer technology and third, to provide a parsimonious theoretical explanatory model (Davis, Bagozzi \& Warshaw, 1989). This model therefore seeks to provide a basis for tracing the impact of external factors on internal beliefs, attitudes and intentions.TAM suggests that perceived usefulness and perceived ease of use are the basis for the acceptance of the use of the computer. In addition, external variables such as the characteristics of the system design, the training, self-efficacy regarding the use of the computer, the user involvement in the design of the system and the nature of the process implantation of the system would influence the ICT adoption (Venkatesh \& Davis, 1996). Perceived usefulness (subjective probability) is the degree to which an individual believes that using a technology tool can increase its performance in the task he has done (at work, for example) and perceived ease (respective application) of use translates degree to which a potential user expects that the use of a technological tool asks for a minimum of effort. As with the reasoned action model, TAM advance the intention to use determines the use of this technology.

However, the first model of TAM postulates that intention is itself determined by attitude of the person who deals with system use and perceived usefulness. The relationship between attitude and intention to use a new system is represented in this model. Itimplies that, other things being equal, individuals form their intention to issue a behavior from a positive affect that they endure (Davis, Bagozzi \& Warshaw, 1989). Easiness to communicate by e-communication systems further influences the adopters to deepen their use of those technologies.

In fact, the technology organization and environment (TOE) framework was proposed by Tornatzky, Fleicher, \& Chakrabarti (1990) to identify the three aspects; i). Technological context refers to existing technologies; ii). Organizational context addresses the descriptive measures about organization such as scope, size, and resourcesavailable internally; iii). Environmental context that refers to the aspects of how the organization conducts its businessof an organization's context that influence the process by which it adopts, implements and uses technological innovation. It is important to notice that the impact of environment factors and their characteristics has been addressed in institutional theory, which could be synthesized with adoption and innovation diffusion theories. Institutional theories posit that organizations face different pressures to conform 
to these share notions of appropriate forms of behaviors. The researches of DiMaggio \& Powel (1988) allow distinguishing three types of isomorphic pressures. The first is normative that argues that in organizational context, a focal organization is able to learn about an innovation and its associated benefits and costs from other user organizations that are directly or indirectly tied with them, and is likely to be persuaded to behave similarly (Burt, 1982). The second in mimetic pressures those are related to the influences of other structurally equivalent organization that have initiated some innovations successfully. These pressures may cause an organization to change over time to become more like other organization in its environment. The third, coercive pressures address various kindsof powers or influences, informal or formal, exercises initiated some innovations upon which they are dependent. Coercive pressures have been considered as an influencer in past ICT adoption studies (Quaddus \& Hofmeyer, 2007). This study also explores the positive influence of normative, mimetic and coercive pressures in public administration to use e-mail communication in the context of Benin.

Some previous studies report a significant link between cultural dimension and different facets of ICT uses (Al-Azad, Mohiuddin, \& Rashid, 2010; Brewer \& Runeson, 2009; Goggins \& Mascaro, 2013; Richards \& Bilgin, 2012). Erumban and Jong (2006) showed that the national culture and ICT adoption rate of a country are related. They further report most of the Hofstede (2001) dimensions are important in influencing adoption where power distance and uncertainty avoidance dimensions seem to be most influential. In Benin public administration, the civil servants are from different ethnics, different background and do possessdifferent views about interpretation of innovations.

Some scholars have made some research to check if the digital communication affects emotional intelligence or interpersonal relationship (Hamon, 2013). It shows that there is nothing wrong with sending email if your objective is to communicate. However, email communication, the first cousin of the texting messages, could compromise interpersonal civility, and even aggression. The research argued that 93 percent of communication is conveyed in tone of voice and body language, while 7 percent is conveyed in the words. Even, it has seen as the ways that allows us to hide the tone of voice, facial expressions, and feelings, email communication can affect interpersonal relationship situations such as job interviews, conflict management, and problem solving with others (Hamon, 2013). Previous researches mostly favor the thought that organization adopt the ICT that is useful and provides them with some economic benefit while, the non-economic factor such as cultural, environment and institution factors were overlooked (Thatcher et al., 2006).

It is evident from the extant literature review that E-communication has generated a lot research from the scholars and practitioners due to the place that ICT occupies in improving the management systems and performances of both public and private organizations (Al-Qudah, Saaty, \& Al-Momani, 2012; Ifinedo, 2006; Ojha, \& Palvia, 2012). In the past, the studies have focuses on different theories about the impact of ICT on the organizations (adaptation and adoption) mostly in developed countries. The present research seeks to address the paucity of research in Africa and especially in Benin's public administration.

\section{Methodology}

\subsection{Research Question}

The research question that was investigated in this study was as follows: What are the obstacles of email communication adoption in developing countries such as in Benin's public administration? It shed also light on the challenges and strategies to adopt for e-communication. The aforementioned research question led us to explore the questions such as: Does email communication affect the competitive advantage of public administration in Benin? Does email communication allow civil servant to improve their performance in their work? Does email communication attract citizen to be satisfied with their fundamental expectations? Can the new challenges posed by email communication for public administration offer a match to deal with citizen needs?

\subsection{Overall Research Approach}

Depending on the nature of the research and the problem to be investigated, either a qualitative or a quantitative approach would generally be more appropriate (Creswell, 2003). A qualitative method rather than a quantitative was preferred for this study due to the exploratory type of research questions we are focusing on. We want to "study a group or population, identify variables that cannot be easily measured, or here in silenced voices" (Creswell, 2013, p. 48). The premise of this study was to describe how civil servantsadopt using email communication in order to align with administration objectives for service quality improvement. The qualitative research helps to deeper into an issueof its pre-paradigmatic era, such as, the e-communication in Benin and explores some nuances related to the obstacles in its implementation. Karami, Rowley, and Analoui (2006) contended that qualitative research method enables researcher to probe for deeper understanding of the issues 
under investigation. Denzin and Lincoln (2005) defined qualitative research as "a situated activity that locates the observer in the world". Malterud $(2001$, p. 483) stated that "qualitative research methods involve the systematic collection [...], and interpretation of textual material derived from talk or observation. According to Cooper and Schindler (2006, p. 196), "qualitative research aims to achieve in-depth understanding of a situation". The expected results for this study were in the format of qualitative data derived from questionnaire consisting of structured question and from documents review.

\subsection{Justification for Using Case Study}

Is case study a valid research tool for this paper? The key challenge for this study had been to identify a research methodology that is able to both capture the complexity of the organizational phenomenon being investigated and identify, and examine not only the components of the phenomenon, but also the connections between them. In business and management discipline, several scholars have affirmed that quantitative methods are often more used, even if case studies and other comparative methods are sometimes more justified (Cassell, Symon, Buehring, Johnson \& Bishop, 2005; Vissak, 2010). The case study is the most flexible of all research designs, allowing the researcher to retain the holistic characteristics of real-life events while investigating empirical events. It is a story about how something exists within real world context that is created by carefully examining an instance. It helps to understand the phenomena that can involve many specific methodologies such as interviews and direct observation. The application of the case study can be useful for transcending the local boundaries of the investigated cases, capturing new layers of reality, and developing new, testable and empirically valid theoretical and practical insights (Eisenhart \& Graebner, 2007; Ghauri, 2004). Yin (1989) finds the use of the case study methodology appropriate when organizational and managerial issues need to be examined. Benbasat, Goldstein and Mead (1987) consider the case study methodology viable for the following three reasons: (i) it is necessary to study the phenomenon in its natural setting; (ii) the researcher can ask how and why questions, in order to understand the nature and complexity of the processes taking place; and (iii) the research being conducted in an era where few, if any, previous studies have been undertaken.

There are several approaches to conduct case study research. Yin (2009) has proposed the following classifications: exploratory, descriptive and explanatory case study. An exploratory case study is undertaken when the available literature or existing knowledge base is poor. Descriptive case studies aims to provide rich, detail description of a phenomenon from which observation are made. Finally, explanatory case studies seek to provide causal explanations. In this research, descriptive seemed appropriate because the goal is to gain knowledge about the phenomenon and to provide readers a common language about the topic in question. This research will help to intend a specific issue, problem or concept about email communication adoption in Benin (single case) based on the ministry of ICT. Our case presents in-depth understanding because we can collect many forms of qualitative data.

\subsection{Data Collection}

According to Cooper and Schindler (2003, p. 87) "Data collection can be achieved through questionnaires, standardized tests, observational forms, laboratory notes, and instruments and instrument calibration logs" This study relied on semi-structured interviews, direct observation and documents analysis as the sources of data in order to gain and understanding of the dynamics of change related to implementation email communication in Benin. We use our computer to store, organized and managed the data as recommended by Yin (1994).

A semi-structured interview approach was found suitable for this study because it can yield unexpected and insightful information, thus enhancing the findings (Hair, Babin, Money \& Samouel, 2003; Marshall \& Rossman, 2011). It gave us a better opportunity to immediately clarify with the interviewee the data that was being sought. A large part of data was gathered through semi-structured interviews with staff members who are directly involved in planning and implementation the email communication not only in the ministry of ICT but also in other ministries departments. A total of 15 interviews (senior managers) were conducted for the study. All interviews were conducted by trained qualitative researchers, digitally recorded, and lasted between 45 minutes and an hour and half. The interview guided was developed based on the review of the current literature and were grouped into three fundamental topics: obstacles of email communication adoption in Benin, the organizational components in managing change, and the effect of change in the public administration.The interviews were transcribed, resulting in 368 pages of text. During the interview, we memorize the question and their order to minimize losing eye contact with the participants (Creswell, 2013, p. 169) and we have try to be natural as possible as we can.

Direct observation as a method of data collection has a several advantages. It provides and additional source of information about email communication in Benin public administration. We have been able to understand, to 
capture the context with the people interacts and to see things that may routinely escape awareness among the people in the setting as recommended Patton (2003). In this study, the author is not a civil servant in the ministry of ICT, so he could not influence the situation under assessment. The data from the observation in this study was used to identify the between what people say, they do and what they actually do.

\subsection{Document Analysis}

Like other analytical methods in qualitative research, document analysis requires that data be examined and interpreted in order to elicit meaning, gain understanding, and develop empirical knowledge (Corbin \& Strauss, 2008). Documents that may be used for a study take a variety forms. They could include advertisements, agendas, attendance registers and minutes of meetings, manuals, background papers, books and brochures, diaries and journals, event programs map, newspapers, program scripts, program proposals, summaries, radio and television, organizational or institutional reports, survey data, academic papers, and various public reports.

Bowen (2009) identified five specific functions of specific functions of documentary material. First, documents can provide data on the context within which research participants operate. Second, information contained in documents can suggest some questions that need to ask and situations that need to be observed as part of the research. Third, documents provide supplementary research data. Fourth, documents provide a means of tracking change and development. Where various drafts of a particular document are accessible, the researcher can compare, the researcher can compare them to identity the changes. Fifth, documents can be analyzed as a way to verify findings or corroborate evidence from other sources. For the current study, documents from the ministry of ICT provide valuable information on contextual factors influencing the e-communication adoption since 1994.

Table 1. Synthesis of codification from data collection

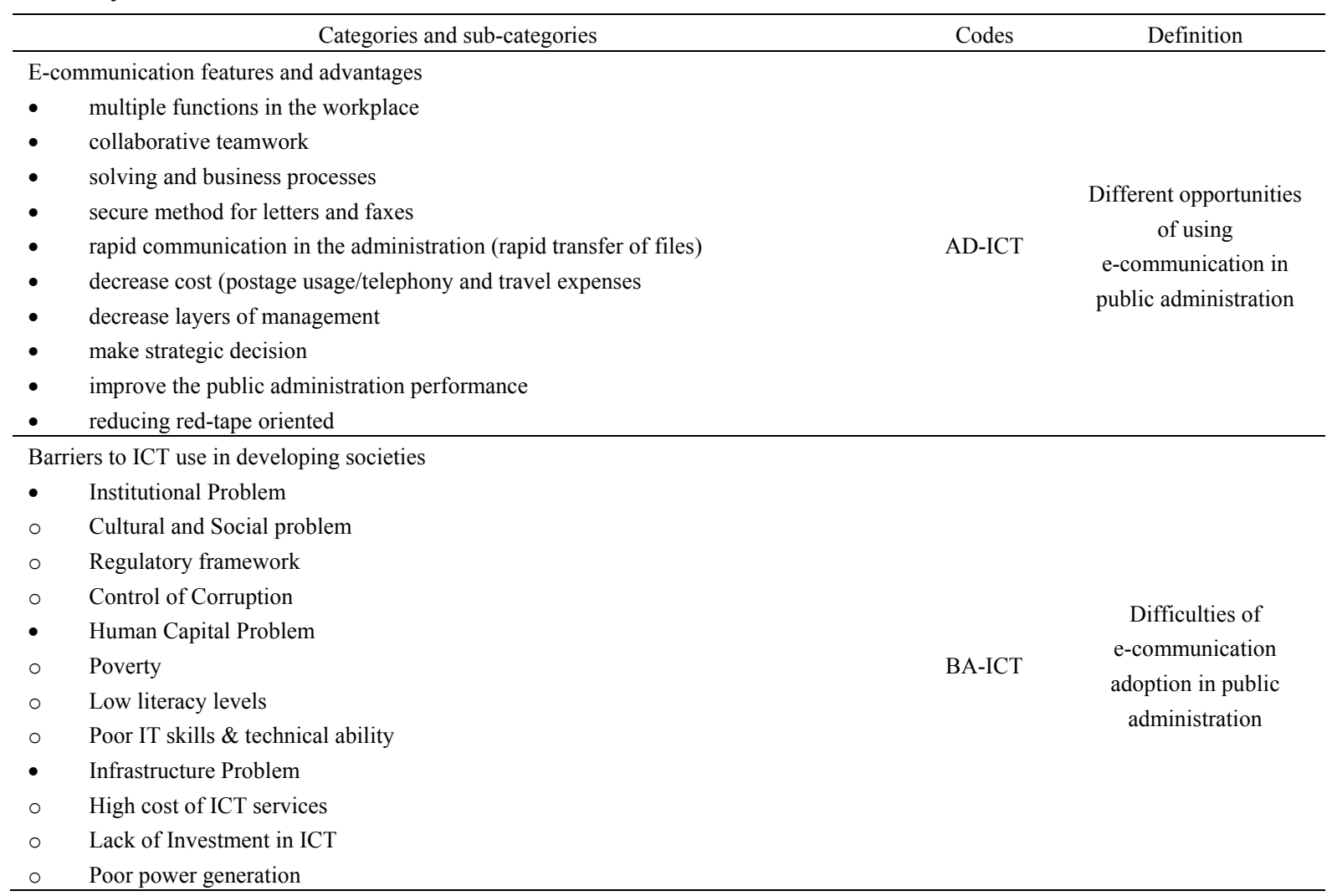


Initiatives on the ICT adoption in developing countries (Benin)

- $\quad$ create a Center for Information and Security information systems;

- $\quad$ promote of structures and associations involved in the ICT field;

- $\quad$ promote research and development center in the ICT field;

- $\quad$ establish of monitoring-evaluation policy and strategies;

- $\quad$ establish and operationalize of funds to support ICT;

- $\quad$ human capacity building;

- $\quad$ equipping all schools and universities of ICT;

- develop a capacity to generate endogenous ICT;

- $\quad$ share between workers the benefits of electronic messages;

\subsection{Data Analysis}

Qualitative content analysis is one of numerous research method used to analyze text data (Sultana, Rashid, Mohiuddin, \& Mazumder, 2013). It is widely used as qualitative research technique. In case study research, data analysis follows an iterative process, proceeding from more general to specific observations (Creswell, 2013). This analysis could start during the data collection phase and continue through the data transcription stage, when themes, pattern and categories becomes apparent.

Our data analysis consisted in three distinct stages. The first started with the process of coding and subsequently organizing the data in the conceptual categories. The process involve a careful, more focused re-reading and review of the data and performed coding and category construction based on the data characteristics to uncover themes pertinent to the phenomenon (See Table 1).

For Creswell (2013, p. 184) "code or category represents the heart of the qualitative data analysis". For this study, the strategy of coding interview, documents and observations data enabled to ensure consistency with theoretical construct of the study. This initial coding proceeded, new themes and codes were discovered, some were added and existing one have been modified. The next stage of the analysis involved constructing of a case description and interpretation (Miles \& Huberman, 1994). This technique helped to reduce the large volume of data and combined data from all three sources. The final stage of analysis entailed of using software to guide the research. In fact, since a decade, there are different tools that can assist scholars in their research. To make our most faithful to the narrative and the reality of our observation analysis, we used the QDA Miner software. Even if the software world is changing at lightning speed and dizzying, QDA Miner according to Milon\& Dragon (2007) is characterized by the simplicity of its functions. It is appropriate software that fit with our study.

\subsection{Validity and Reliability}

To maximize the content and face validity of the dimensions generated from the descriptive research, we have adopted four tests developed by Ying (2003). They are: (i) construct validity (multiple sources of data were collected for the case under investigation in order to increase construct validity), (ii) internal validity (we have maintained a logic chain of evidence; the reader can follow the derivation from any evidence from our research questions to the final conclusion. More the triangulation of different sources (used in convergence) of evidence was important way of increasing the internal validity of this study), (iii) external validity (we attempted to sharpen the external validity in the way that we have chosen the case study and conducted the research. The findings from this study can be generalized and replicate if conducted in the same conditions) and (iv) reliability (It is the consistency and stability of the research process (Miles \& Huberman, 2003). To avoid errors and provide more reliability to our research, this work is coupled with a content analysis that requires an analysis of documents. This ultimately allowed us to extract some key ideas while assigning a code to each).

\subsection{Ethical Considerations and Reflexivity}

The ethical considerations of this study revolved around informed consent, confidentiality and potential harm to participants. We have contacted our participants by email to see if they are interested in participating in the study and accepted to sign the informed consent form. We also respect the privacy, confidentiality and anonymity (Sieber 1992) of the participant. The results of this research will not be diverted or used for personal purposes (impartiality) and all information collected has treated in confidential manner.

In this study the reflexivity facilitated understanding of both phenomenon studied and the research process (Watt, 2007). Reflexivity implied that author "should explicitly position themselves in relation to their objects of 
study so that one may assess researchers's knowledge claims in terms of situated aspects of their social selves and reveal their (hidden) doxic values and assumptions" (Maton, 2003, p. 54).

\section{Findings}

Organizational theory states that there is no identical organization in the world. Each organisation is unique and has its own peculiarities. Governments 'ministries' in developing countries have different strategies and view about ICT policies. They also have different corporate culture which is aggregation of individual behaviour or perception. In the document related to the ICT Policy and Strategies (2003), Benin recognizes that ICTs offer many opportunities for development in any country through accelerating economic growth and employment promotion. It is on this basis that the Government of the Republic of Benin is committed to having an effective national policy for ICT development through which the country can seize the opportunities of its socio-economic development. According to that foregoing, Benin has a strong will to improve and promote the skills of the ICTs. However, the conditions surrounding the public and private initiatives failed to achieve a harmonious development and effective use of ICT to benefit the stakeholders in Benin.

According to different themes which have beendeveloped, e-communication adoption is associated to several dimensions that are associated to TAM. We can identify organizational dimension, sociocultural dimension and individual ones. Organizational dimensions are related to the different support or training given by the government to the employees. Sociocultural dimension are defined as the influence of people around IT users including internalization, image and collective perception. Individual dimension is viewed as cognitive factors that related to outcomes of ICT including job relevance, qualification, and output quality and result demonstrability.

The figure 1 below shows organizational, sociocultural and individual dimensions that affect ICT adoption in Benin. The Government adopted the national policy on information technology and communication in the 1990s. However, the framework to encourage technological innovation, use, security and protection of computer data in the system is absent. Furthermore, high corruption rate in Benin (Transparency International, 2012) and the regional culture (that is not so open to adopt ICT and considered as a foreign technology) do not promote the use and the emergence of e-communication in the Benin's Public administration.

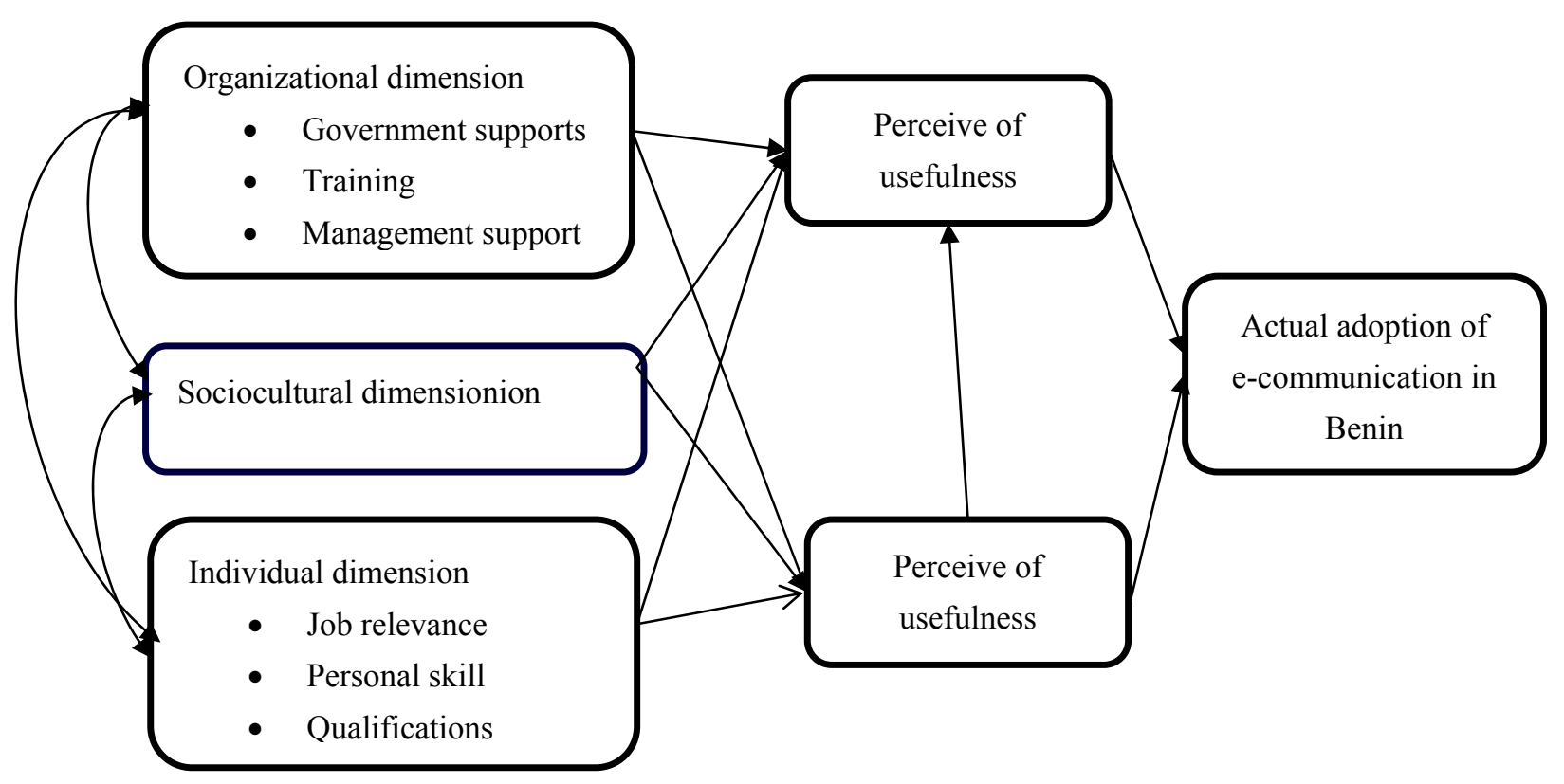

Figure 1. Structural relationship between e-communication adoption's dimensions

According to the World Bank report, Benin is associated with Low literacy level, low GDP per capita and low educational attainment. In terms of administrative services of the state, qualified human resources are inadequate and low level of access to information is a serious hindrance to the development of services and their operation and improvement. Thus, most of the permanent staff of the Stateare unable to use electronic messages to transfer 
administrative documents to the citizens who are supposed to receive services from the civil service of the state. It is also important to note thetype of the Beninese civil service, the majority of them are already old and had not "known or lived" during the era of computerization. Computer literacy remains low in 50 or above aged civil servants. This situation is further aggravated by the high cost of computers in Benin, low level of computerization of administrative services and inadequate training. In terms of energy, the electrification rate of the country is $22 \%$. This low rate is a major impediment to the development of ICT. In addition $90 \%$ of the electricity distributed in Benin is imported.Most of the household in West African countries have no telephone (Abodohoui, 2010; Ifinedo, 2006; Ray, 2012). The data collected from World Economy Forum (2008) show that most of West African countries and specially Benin lag behind in using the ICT. Some initiatives needed to be formulated as the institutionalization of ICTs could ensure a regulatory and legislative environment. A capacity building of human resources available to conduct the necessary reforms (Batoko, 2004) to the advent of the information society in Benin or in developing countries should be the ambition of perpetual strategies in Benin. The Government of Benin should also think of equipping all schools and universities with ICTequipmentand creatinga specialized institute in ICT, while developing a capacity to generate endogenous ICT. The implementation of a mechanism for monitoring and evaluation of policy and strategies must be envisaged, which will help to lead the policies wisely.

\section{Conclusion, Limitations and Future Research}

The research showed that ministries of different governments have different strategies for adoption of ICT policies and practices. They also have different corporate culture which is aggregating individual behaviour or perception. The authors identified that e-communication adoption is associated to several dimensions that are associated to technology acceptance model (TAM). These dimensions are organizational dimension, sociocultural dimension and individual dimension. The findings also suggest that the best policy may be to start using e-communication in different administration continuously and it will help civil servant and citizen to get acquainted with the new system. The results of this study can be used to reinforce e-communication adoption in developing countries and keep the public administration within the easy reach of its citizens. It will enable the governments to offer better public services. Information and Communication Technologies (ICT) are understood as a resource with the potential to improve the efficiency and effectiveness of Public Administration.

E-communications have received little critical attention. Although there are some articles about e-mails, there is very little scholarly research in communication, organizational behavior or public relations and especially in Africa (Benin). All forms of professional communication involves risks (Michael, 2008). The use of computers for communication is subject to other risks like: spamming, the use of e-mail eliminate face-face communicationwhile exposing crucial data to impending dangers of virus threat and pornography (O'Rourke, 2012). Governments must introduce new technology for e-security, and must also implement the code of ethics and deontology in respect of ICT in the workplace. The advent of e-mail has created a modern social space in which persons, workers and civil servant can interact with each over. The spectrum of e-mail communication is enormous. It provides faster access to government information, lower administrative cost and increase transparency in government departments, reduces bribery and corruption. For developing countries, it poses a real problem of ownership of ICT which may be a lever for development in all areas. In Benin, the advantages of the electronic message (Azam \& Quaddus, 2012) are well known, but circumstantial and laudable policies are slow to fill the gap despite the computing resources available to the country. All development actors (government, institutions, development partners, private sector, and individual) must be mobilized to top actions and strategies for success. E-mail gives some prestigious opportunities to employees, managers and enhances the country's economy.

The main contribution of this paper is to highlight the impediments of the e-communication adoption in developing countries. This study contributes to dimensions of ICT adoption by adding a cultural factor to the theory of technology acceptance model (TAM). A significant research has been done about e-Business in West-African countries. The rate of ICT adoption remains extremely low. These countries need to find a reliable way to embark on the digital economy in order to become viable economically and improve their economies and the living standard of their population (Abarchi \& Yong, 2011).

Despite taking in account several precautions and measure to respect the criteria of a scientific work, our research has certain limitations. The work presents some limits, both methodological and empirical. The findings of case study research are difficult to generalize on a population beyond cases similar to those studies (Yin, 2003). Empirically, the heterogeneity of the background of the manager that we have interviewed caused certain level of interpretation because they have been abroad to study and know more about usage of ICT. It implies that results of this study arenot generalizableto all developing countries or to all West African countries. 
Future research needs to analyze the impact of the implementation of e-communication in the public administration with larger samples.

\section{References}

Abarchi, A. T., \& Yong, T. B. (2011). Leveraging Economic Development with e-Business in West African Developing Countries. International Journal of e-Education, e-Business, e-Management and e-Learning, 1(5), 390-400.

Abodohoui, A. (2010). Towards E-HRM in ECOWAS Countries: Impedimentsand Initiatives. 14th UNESCO-Asia Pacific of Educational Innovation for Development (APEID), Bangkok-Thailand.

Agarwal, R., \& Prasad, J. (1997). The role of innovation characteristics and perceived voluntariness in the acceptance of information technologies. Decision sciences, 28(3), 557-582.

Ajzen, I., \& Fishbein, M. (1980). Understanding attitudes and predicting social behavior. Englewood-Cliffs, NJ: Prentice-Hall.

Al-Azad, M. S., Mohiuddin, M., \& Rashid, M. M. (2012). Knowledge Transfer in Offshore Outsourcing and International Joint Ventures (Ijvs) - A Critical Literature Review from Cross-Cultural Context. Global Journal of Strategies \& Governance, 1(1), 41-67.

Al-Qudah, H. S. S., Saaty, A. S. A., \& Al-Momani, A. A. M. (2012). Impact of Information Technology on Management Control at Al Bashir Public Hospital: A Case Study of Jordan. International Journal of Business and Management, 7(2), 260-276. http://dx.doi.org/10.5539/ijbm.v7n2p260

Asogwa, B. E. (2013). Electronic government as a paradigm shift for efficient public services. Library Hi-Tech, 31(1), 141-159. http://dx.doi.org/10.1108/07378831311303985

Azam, M. S., \& Quaddus, M. (2012). Effects of internal and external factors on internet-based digital technology usage by SMEs in a developing country. Communications of the IIMA, 12(4), 41-69. Retrieved from http://search.proquest.com/docview/1346907336?accountid=12008

Batoko, O. (2004). Supporting Africa's Efforts to Achieve Sustainable Development: Dialogues of the Economic And Social Council. United Nations Publications.

Beer, M., Eisenstat, A., \& Spector, B. (1990). The critical path to corporate renewal. Cambridge: Harvard Business School Press.

Bowen, \& Glenn, A. (2009). Document Analysis as a Qualitative Research Method. sQualitative Research Journal, 9(2), 27-40. http://dx.doi.org/10.3316/QRJ0902027

Brewer, G., \& Runeson, G. (2009).Innovation and attitude. International Journal of Managing Projects in Business, 2(4), 599-610. http://dx.doi.org/10.1108/17538370910991179

Cassell, C., Buehring, A., Symon, G., Johnson, P., \& Bishop, V. (2005). Research Report: Benchmarking good practice in qualitative management research. London: Economic.

Cheng, A. (2013). Are you assuming unnecessary risks associated with franchisee email accounts? Franchising World, 45(3), 19-20. Retrieved from http://search.proquest.com/docview/1327311100?accountid=12008

Cooper, D. R., \& Schindler, P. S. (2003). Business Research Methods (8th ed.). USA: McGraw-Hill.

Cooper, D., \& Schindler, P. (2006). Business Research Methods. New York: McGraw-Hill.

Corbin, J., \& Strauss, A. (2008). Basics of qualitative research: Techniques and procedures for developing grounded theory (3rd ed.). Thousand Oaks, CA: Sage.

Creswell, J. (2003). Research design: Qualitative, quantitative, and mixed method approaches. Thousand Oaks, CA: Sage Publications.

Creswell, J. W. (2013). Qualitative inquiry and research design: Choosing among five approaches (3rd ed.). Sage Publications.

Denzin, N., \& Lincoln, Y. (2005). Thousand Oaks. The Sage handbook of qualitative research (3rd edition) California: Sage Publications.

DiMaggio P. (1988). Interest and Agency in Institutional Theory. In L. Zucker (Ed), Institutional Patterns and Organizations: Culture and Environments (pp. 3-21). Cambridge, MA:Ballinger.

Duhon, B. (2008). Become an email master. AIIM E-Doc Magazine, 22(3), 60. Retrieved from $\mathrm{http}: / /$ search.proquest.com/docview/216583831?accountid=12008 
Eisenhardt, K. M., \& Graebner, M. E. (2007). Theory building from cases: Opportunities and challenges. Academy of Management Journal, 50(1), 25-32.

Ernst \& Young Telecommunications Industry. (2009). Africa connected: A telecommunications growth story. Retrieved from http://www.chairmanking.com/wpcontent/uploads/2009/07/africa connected a Telecommunications growth story.pdf

Erumban, A. A., \& De Jong, S. B. (2006). Cross-country differences in ICT adoption: A consequence of culture? Journal of World Business, 41(4), 302-314.

Farrell, D., Laboissiere, M. A., \& Rosenfeld, J. (2006). Sizing the emerging global labor market: rational behavior from both companies and countries can help it work more efficiently. The Academy of Management Perspectives, 20(4), 23-34.

Fereday, J., \& Muir-Cochrane, E. (2008). Demonstrating rigor using thematic analysis: A hybrid approach of inductive and deductive coding and theme development. International Journal of Qualitative Methods, 5(1), $80-92$.

Fernandez-Alles, M., \& Valle-Cabrera, R. (2006). Reconciling institutional theory with organisational theories: how neo-institutionalism resolves five paradoxes. Journal for Organisational Change Management, 19(4), 503-517.

Fishbein, M., \& Ajzen, I. (1975). Belief, attitude, intention, and behavior: An introduction to theory and research. Reading, MA: Addison-Wesley.

Ghauri P. (2004). Designing and conducting case studies in international business research. In: MarschanPiekkari, R., \& Welch, C. (Eds.), Handbook of qualitative research methods for international business (pp. 109-124). Northampton, MA.

Goggins, S. P., \& Mascaro, C. (2013). Context matters: The experience of physical, informational, and cultural distance in a rural IT firm. Information Society, 29(2), 113. Retrieved from http://search.proquest.com/docview/1313957966?accountid=12008

Guba, E. G., \& Lincoln, Y. S. (1994). Competing paradigms in qualitative research. In N. K. Denzin \& Y. S. Lincoln (Eds.), Handbook of Qualitative Research (pp.105-17). Newbury Park, CA: Sage.

Gupta, A., Diallo, C., Marot, M., \& Becker, M. (2010). Understanding topology challenges in the implementation of wireless sensor network for cold chain.

Hair, J. F. J., Babin, B., Money, A. H., \& Samuel, P. (2003). Essentials of Business Research Methods. USA: John Wiley and Sons, Leyh Publishing, LLC.

Harmon, P. (2013). Does texting affect emotional intelligence? $T+D, 67(7)$, 70-71. Retrieved from $\mathrm{http}: / /$ search.proquest.com/docview/1418437999? accountid=12008

Hofstede, G. H. (2001). Culture's consequences: Comparing values, behaviors, institutions and organizations across nations. Sage.

Ifinedo, P. (2006). Towards e-government in a Sub-Saharan African country: Impediments and initiatives in Nigeria. Journal of E-Government, 3(1), 3-28.

Jabeur, F., Mohiuddin, M., \& Karuranga, E. (2013). Timeline of Initial Perceptions and Adoption of E-business Among Quebec Forestry Sector SMEs. Communications of the IIMA, 13(3).

Karami, A., Rowley, J., \& Analoui, F. (2006). Research and knowledge building in management studies: An analysis of methodological preferences. International Journal of Management, 23, 43-52.

Krishnaswamy, J., Bonell, M., Venkatesh, B., Purandara, B. K., Lele, S., Kiran, M. C., \& Rakesh, K. N. (2012). The rain-runoff response of tropical humid forest ecosystems to use and reforestation in the Western Ghats of India. Journal of Hydrology.

Kyriakidou, V., Michalakelis, C., \& Sphicopoulos, T. (2013). Assessment of information and communications technology maturity level. Telecommunications Policy, 37(1), 48. Retrieved from http://search.proquest.com/docview/1285278486? accountid=12008

Marshall, C., \& Rossman. G. B. (2011). Designing Qualitative Research (5th ed.). Thousand Oaks, CA: Sage Publications.

Martin, B. L. (2012). Hitting or Missing African UAS Objectives? An Evaluation of Universal Access and Service (UAS) Policy Guidelines for Developing Countries. Communications \& Strategies, 2(86), 
$121-141$.

Maton, K. (2003). Pierre Bourdieu and the episteme conditions of social scientific knowledge. Space and Culture, 6(1), 52-65.

McCrory, R. (2011). Legal minefield. The British Journal of Administrative Management, 26-27. Retrieved from http://search.proquest.com/docview/1348873111?accountid=12008

Michael, L. K. (2008). Critical analysis of blogging in public relations. Public Relations Review, 34, 32-40.

Miles, M. B., \& Huberman, A. M. (1994). Qualitative data analysis (2nd eds.). Thousand Oaks, CA: Sage.

Miles, M.B., \& Huberman, A. M. (2003). Analyse des données qualitatives (2nd ed.). Paris: De Boeck.

Miron, J. M., \& Dragon, J. F. (2007). La recherche qualitative assistée par ordinateur pour les budgets minceurs, est-ce possible. Recherchesqualitatives, 27(2), 152-175.

Moore, G. C., \& Benbasat, I. (1991). Development of an instrument to measure the perceptions of adopting an information technology innovation. Information Systems Research, 2(3), 192-222.

Ojha, A., \& Palvia, S. (2012). E-government and the fight against corruption: conceptual model AND five case studies from Indiadagger. Journal of Information Technology Case and Application Research, 14(4), $11-29$.

O'Rourke, M. (2012). RE-Evaluating email. Risk Management, 59(1). Retrieved from $\mathrm{http}: / /$ search.proquest.com/docview/1012096640?accountid=12008

Patton, E., \& Appelbaum, S. H. (2003). The case for case studies in management research. Management Research News, 26(5), 60-71. Qualitative Methods, 5(1), 80-92.

Quaddus, M., \& Hofmeyer, G. (2007). An investigation into the factors influencing the adoption of B2B trading exchanges in small business. European Journal of Information Systems, 16(1), 202-215.

Ray, J. S. (2012). Leveling E-commerce opportunities for developing countries. http://dx.doi.org/10.2139/ssrn.2108365

Richards, D., \& Bilgin, A. (2012). Cross-cultural study into ICT student attitudes and behaviours concerning teams and project work. Multicultural Education \& Technology Journal, 6(1), 18-35. http://dx.doi.org/10.1108/17504971211216292

Rogers, E. M. (1983). Diffusion of innovations (3rd ed.). New York: Free Press.

Sieber, J. E. (1992). Planning ethically responsible research: A guide for students and internal review boards. Newbury Park, CA: Sage

Sultana, M. A., Rashid, M. M., Mohiuddin, M., \& Mazumder, M. N. H. (2013). Cross-Cultural Management and Organizational Performance: A Content Analysis Perspective. International Journal of Business and Management, 8(8), 133-146. http://dx.doi.org/10.5539/ijbm.v8n8p133

Tan, M., \& Teo, T. S. H. (2000). Factors influencing the adoption of internet banking. Journal of the Association for Information Systems, 1(1), 1-42.

Thatcher, J. B., Brower, R. S., \& Mason, R. M. (2006). Organizational fields and the diffusion of information technologies within and across the nonprofit and public sectors: A preliminary theory. American Review of Public Administration, 36(4), 437-454.

Tornatzky, L. G., \& Fleischer, M. (1990). The Processes of Technological Innovation. Lexington, MA: Lexington Books.

Transparency International Corruption Perception Index. (TICP). Global Corruption Report. Retrieved from http://www.transparency.org/content/search

UNPAN. (2005, 2008). UN e-Government Survey 2008, From e-Government to Connected Governance. Retrieved from http://www.unpan.org/egovkb/global_reports/08report.htm

Valier, F. M. (2006). A primary study of perceived characteristics of innovations and intent to use open source software in business. Retrieved from http://search.proquest.com/docview/304909602?accountid=12008

Venkatesh, V., \& Sykes, T. A. (2013). Digital divide initiative success in developing countries: A longitudinal field study in a village in india. Information Systems Research, 24(2), 239-260.

Vissak, T. (2010). Recommendations for Using the Case Study Method in International Business Research. The 
Qualitative Report, 15(3), 370-388. http://www.nova.edu/ssss/QR/QR15-2/vissak.pdf

Watt, D. (2007). On becoming a qualitative researcher: the value of reflexivity. The Qualitative Report, 12(1), 82-101. Retrieved from http://www.nova.edu/ssss/QR/QR12-1/watt.pdf

Weilbach, L., \& Byrne, E. (2010). A human environmentalist approach to diffusion in ICT policies: a case study of the FOSS policy of the South African Government. Journal of Information, Communication and Ethics in Society, 8(1), 108-123.

Yin, R. K. (1989). Case study research: design and methods. Newbury Park, CA: Sage.

Yin, R. K. (1994). Case study research: design and methods (2nd ed.). Thousand Oaks, CA358 T. R.: Sage.

Yin, R. K. (2003). Applications of case study research (2nd ed.). Thousand Oaks, CA: Sage Publications.

Yin, R. K. (2009). Case study research: Design and methods (4th ed.). Thousand Oaks, CA: Sage Publications.

Zhu, K., \& Kraemer, K. L. (2005). Post-adoption variations in usage and value of e-business by organizations: cross-country evidence from the retail industry. Information Systems Research, 16(1), 61-84.

\section{Copyrights}

Copyright for this article is retained by the author(s), with first publication rights granted to the journal.

This is an open-access article distributed under the terms and conditions of the Creative Commons Attribution license (http://creativecommons.org/licenses/by/3.0/). 